\title{
Estimasi Biaụa Konstruksi Pada Perumahan Tipe 45 di Sulawesi Tengah Menggunakan Regresi Kuadratik
}

\author{
A. Rizala*, M. Fajri ${ }^{a}$ dan L.S.Yuniar \\ a Jurusan Teknik Sipil, Fakultas Teknik Universitas Tadulako, Palu \\ *Corresponding author's e-mail: gitarggbeud@gmail.com
}

Received: 18 August 2020; revised: 24 August 2020; accepted: 25 August 2020

\begin{abstract}
This research is based on the background of the problem that cost estimation is very beneficial for the owner, contractor and consultant. Errors in estimating costs are very often done, this is due to lack of experience and information obtained by an estimator. The purpose of this study is to obtain an equation that can help an estimator in estimating costs whose results approach the actual cost and can speed up the estimation process. The data that used in this research is from RAB's 45 type house in Central Sulawesi. The method that will be used in this research is Pearson Correlation and Quadratic Regression. Pearson correlation is used to see the correlation between the independent and dependent variables while the Quadratic Regression is used to get the equation between the independent variable and the dependent variable. Regression modeling results obtained are $\widehat{\boldsymbol{y}}=-\mathbf{6 4 9}, \mathbf{1 5} X_{\mathbf{1}}+\mathbf{0 , 0 0 2 2} X_{\mathbf{1}}^{\mathbf{2}}+\mathbf{1 8 2} \boldsymbol{X}_{\mathbf{3}}-\mathbf{0 , 0 0 0 5} \boldsymbol{X}_{\mathbf{3}}^{\mathbf{2}}+\hat{\boldsymbol{e}}$, with $\mathrm{R}^{2}=$ $95 \%$. The variables that significant in this research are raw material $\left(\boldsymbol{X}_{\mathbf{1}}\right)$ and concrete brick $\left(\boldsymbol{X}_{\mathbf{3}}\right)$.
\end{abstract}

Keywords: cost estimation, correlation, quadratic regression.

\begin{abstract}
Abstrak: Penelitian ini dilatarbelakangi oleh masalah bahwa estimasi biaya sangat menguntungkan bagi pemilik, kontraktor dan konsultan. Kesalahan dalam memperkirakan biaya sangat sering dilakukan, hal ini disebabkan oleh kurangnya pengalaman dan informasi yang diperoleh oleh seorang estimator. Tujuan dari penelitian ini adalah untuk mendapatkan persamaan yang dapat membantu seorang estimator dalam mengestimasi biaya yang hasilnya mendekati biaya yang sebenarnya dan dapat mempercepat proses estimasi. Data yang digunakan dalam penelitian ini adalah beberapa rumah tipe RAB 45 di Sulawesi Tengah. Metode yang akan digunakan dalam penelitian ini adalah Korelasi Pearson dan Regresi Kuadratik. Korelasi Pearson digunakan untuk melihat korelasi antara variabel independen dan dependen sedangkan Regresi Kuadrat digunakan untuk mendapatkan persamaan antara variabel independen dan variabel dependen. Hasil pemodelan regresi yang diperoleh adalah $\hat{y}=-649,15 X_{1}+0,0022 X_{1}^{2}+182 X_{3}-0,0005 X_{3}^{2}+\hat{e}$, dengan $R^{2}=95 \%$. Variabel yang signifikan dalam penelitian ini adalah bahan baku $\left(\mathrm{X}_{1}\right)$ dan batako $\left(\mathrm{X}_{3}\right)$.
\end{abstract}

Kata kunci: estimasi biaya, korelasi, regresi kuadrat.

\section{Pendahuluan}

Estimasi biaya merupakan usaha yang dilakukan untuk memprediksi atau memperkirakan nilai suatu pekerjaan melalui analisis perhitungan yang berdasarkan pada pengalaman atau informasi yang didapatkan pada saat itu. Estimasi biaya sangat bermanfaat bagi pemilik proyek, konsultan dan kontraktor.

Estimasi biaya perlu dilakukan dengan cermat karena dalam manajemen konstruksi, estimasi ini memiliki peran fundamental diantaranya adalah sebagai bahan: perencanaan, studi kelayakan, penawaran, perjanjian kontrak kerja, pengendalian, dan pengawasan, perkiraan kebutuhan material/peralatan/tenaga kerja, menentukan harga jual/beli, perkiraan keuntungan [1-8].

Seorang estimator sering sekali melakukan kesalahan dalam melakukan estimasi biaya. Hal ini dapat disebabkan karena pengalaman dan informasi seorang estimator sangat sedikit. semakin sedikit pengalaman dan informasi yang dimiliki seorang estimator maka estimasi yang dilakukan akan semakin tidak mendekati biaya sebenarnya atau actual cost dan semakin lama proses estimasi yang akan dilakukan oleh seorang estimator [9].

Estimasi biaya merupakan bagian proses konstruksi yang sangat mendasar [10]. Secara umum ada dua macam metode menghitung estimasi yang biasa digunakan, yaitu Estimasi Kasar dan Estimasi Terperinci. Cara yang banyak digunakan untuk menghitung estimasi biaya terperinci tersebut adalah dengan menyusun Rencana Anggaran Biaya (RAB) [10].

Estimasi biaya merupakan hal penting dalam dunia industri konstruksi. Ketidak-akuratan dalam estimasi dapat memberikan efek negatif pada seluruh proses konstruksi dan semua pihak yang terlibat. Fungsi dari estimasi biaya dalam industri konstruksi adalah:

a) Untuk melihat apakah perkiraan biaya konstruksi dapat terpenuhi dengan biaya yang ada.

b) Untuk mengatur aliran dana ketika pelaksanaan konstruksi sedang berjalan.

c) Untuk kompetensi pad saat proses penawaran [11]. Estimasi biaya berdasarkan spesifikasi dan gambar kerja yang disiapkan pemborong harus menjamin bahwa pekerjaan akan terlaksana dengan tepat dan kontraktor dapat menerima keuntungan yang layak.

Dalam ilmu statistik terdapat suatu ilmu yang dapat digunakan untuk melakukan prediksi atau perkiraan tentang karakteristik kualitas ataupun kuantitas. Metode tersebut adalah Simple Linear Regression atau Regresi Linear Sederhana. Metode Simple Linear Regression diharapkan 
mampu mendapatkan persamaan agar proses estimasi dapat mendekati biaya sebenarnya dan mempercepat proses dalam perhitungan estimasi yang terdiri dari satu variabel bebas dan satu variabel terikat.

Regresi adalah suatu metode analisis statistik yang digunakan untuk melihat pengaruh antara dua atau lebih variabel. Hubungan variabel tersebut bersifat fungsional yang diwujudkan dalam suatu model matematis. Analisis regresi digunakan untuk mengetahui bagaimana variabel terikat dapat diprediksi melalui variabel bebas secara individual.

Teknik analisis regresi adalah suatu teknik yang dapat digunakan untuk menghasilkan hubungan dalam bentuk numerik dan untuk melihat bagaimana dua (simple regression) atau lebih (multiple regression) variabel saling terkait. Umumnya analisis regresi yang digunakan adalah analisis regresi linear sederhana atau berganda, yang mempunyai indikasi variabel dependent maupun variabel independent yang digunakan bersifat numerik. Selain itu, dalam regresi linear, juga mensyaratkan pemenuhan beberapa asumsi klasik pada datanya, yaitu asumsi normalitas, homogenitas, auto korelasi dan multikolinearitas [12].

Analisis regresi linear punya beberapa keunggulan dari analisis lainnya, di antaranya adalah metode ini sangat mudah diinterpretasikan, perhitungan yang sangat jelas, dan punya model yang bisa divisualisasikan ke dalam bentuk grafik. Namun, metode ini juga punya kekurangan, yaitu tidak dapat digunakan jika data yang dianalisis tidak berbentuk data numeric, sangat sensitive terhadap penambahan variabel, dan juga tidak dapat digunakan jika asumsi klasiknya tidak terpenuhi [12]. Untuk itu, jika analisis regresi linear tidak dapat digunakan, salah satu metode yang bisa digunakan adalah analisis regresi kuadratik.

Analisis regresi kuadratik adalah pengembangan dari regresi linear, dimana data yang dimodelkan dalam regresi kuadratik mempunyai atau membentuk pola kuadrat jika divisualisasikan ke dalam grafik atau diagram.Bentuk umum dari regresi kuadratik adalah [13]:

$$
\hat{y}=b_{0}+b_{1} X_{1}+b_{2} X_{1}^{2}+\cdots+b_{n} X_{n}+b_{n+1} X_{n}^{2}+\hat{e}
$$

dengan:

$y=$ Variabel tidak bebas

$X=$ Variabel bebas

$b_{0}=$ Konstant $/$ Intercept

$b_{n}=$ Slope

Setelah persamaan regresi terbentuk, ada beberapa langkah yang harus dilakukan dalam prosedur analisisnya, yaitu:

1) Pengujian simultan parameter regresi dengan menggunakan uji F pada tabel ANOVA

2) Pengujian parsial dengan menggunakan uji $t$

3) Menentukan nilai R-square atau koefisien determinasi [12].

Sebelum melakukan analisis regresi, idealnya data yang akan dimodelkan lebih dahulu dianalisis dengan menggunakan analisis korelasi. Korelasi berarti hubungan timbal balik [14]. Besar kecilnya korelasi selalu dinyatakan dalam bentuk angka yang kemudian disebut koefisien korelasi. Koefisien korelasi digunakan untuk mengetahui keeratan hubungan dan arah hubungan antara dua variabel. Persamaan korelasi yang digunakan:

$$
r=\frac{n \sum x_{i} y_{i}-\left(\sum x_{i} y_{i}\right)}{\sqrt{\left\{n \sum x_{i}^{2}-\left(\sum x_{i}\right)^{2}\right\}\left\{n \sum y_{i}^{2}-\left(\sum y_{i}^{2}-\left(\sum y_{i}\right)^{2}\right)\right\}}}
$$

dengan:

$\mathrm{r} \quad=$ koefisien korelasi

$\mathrm{n}=$ Banyaknya Pasangan data $\mathrm{X}$ dan $\mathrm{Y}$

$\Sigma \mathrm{x}=$ Total Jumlah dari Variabel $\mathrm{X}$

$\Sigma \mathrm{y}=$ Total Jumlah dari Variabel Y

$\Sigma \mathrm{X}^{2}=$ Total Jumlah Variabel $\mathrm{X}$ yang lebih dulu dikuadratkan

$\Sigma y^{2}=$ Total Jumlah Variabel Y yang lebih dulu dikuadratkan

$\Sigma x y=$ Total Jumlah Variabel X dan Variabel Y yang lebih dulu dikalikan

Tabel 1. Pedoman untuk memberikan interprestasi terhadap koefisien korelasi

\begin{tabular}{cc}
\hline Koefisien Korelasi (r) & Tingkat Hubungan \\
\hline 0 & Tidak berkorelasi \\
\hline-0.2 & Sangat rendah \\
\hline $0.21-0.40$ & Rendah \\
\hline $0.41-0.60$ & Agak rendah \\
\hline $0.61-0.80$ & Cukup tinggi \\
\hline $0.81-0.99$ & Tinggi \\
\hline 1 & Sangat tinggi \\
\hline
\end{tabular}

Koefisien korelasi (r) adalah pengukuran statistik antara dua variabel. Besarnya koefisien korelasi menunjukkan kekuatan (strength) hubungan linear dan arah hubungan dua variabel acak. Jika koefisien korelasi positif, maka kedua variabel mempunyai hubungan searah. Artinya jika nilai variabel $\mathrm{X}$ tinggi, maka nilai variabel $\mathrm{Y}$ akan tinggi pula. Sebaliknya, jika koefisien korelasi negatif, maka kedua variabel mempunyai hubungan terbalik. Artinya jika nilai variabel $\mathrm{X}$ tinggi, maka nilai variabel $\mathrm{Y}$ akan menjadi rendah (dan sebaliknya). Tabel 1 berikut ini adalah untuk memudahkan melakukan interpretasi mengenai kekuatan hubungan antara dua variabel [15].

\section{Metode Penelitian}

Bagian ini berisi uraian tahapan penelitian secara rinci dengan desain, metode, atau pendekatan yang digunakan dalam menjawab permasalahan untuk mencapai tujuan penelitian, tanpa mencantumkan bagan alir penelitian. Sitasi memakai dan daftar pustaka Sistem Number (penomoran sesuai urutan sitasi).

Pengumpulan data diambil secara langsung dari proyek pembangunan rumah sederhana Type 45 yang berada di kota Palu Sulawesi Tengah. Tahapan penelitian yang dilakukan dalam penelitian ini adalah sebagai berikut:

1) Pengumpulan data berupa data RAB (Rencana Anggara Biaya), upah harian tenaga kerja dan harga bahan.

2) Setelah itu melakukan tabulasi data.

3) Kemudian melakukan analisi korelasi untuk mengetahui variabel bebas yang paling berpengaruh positif terhadap 
variabel terikat. Variabel - variabel yang akan dijadikan variabel independen didalam penelitian ini adalah harga bahan baku, upah tenaga kerja dan harga batako. Variabel yang akan dijadikan variabel dependen adalah biaya total konstruksi rumah type 45 per $\mathrm{m}^{2}$.

4) Melakukan analisis regresi dari hasil analisis korelasi.
5) Mendapatkan hasil akhir persamaan regresi untuk estimasi biaya perumahan.

Data yang diperoleh berasal dari data RAB Perumahan Type 45 yang berada di Provinsi Sulawesi Tengah. Setelah data diperoleh, data penelitian ditabulasi seperti pada Tabel 2. Tabel 2 menunjukkan bahwa data yang diperoleh terdiri dari 20 RAB Perumahan Type 45.

Tabel 2. Data penelitian

\begin{tabular}{ccccc}
\hline No & $\begin{array}{c}\text { Bahan Baku (Semen dan } \\
\text { Pasir) (X1) }\end{array}$ & $\begin{array}{c}\text { Upah Tenaga Kerja } / \\
\text { Hari (X) }\end{array}$ & $\begin{array}{c}\text { Batako/100 Buah } \\
(\mathbf{X 3})\end{array}$ & $\begin{array}{c}\text { Biaya Konstruksi / M } \\
(\mathbf{Y})\end{array}$ \\
\hline 1 & 138000 & 85,000 & 140,000 & $1,250,000$ \\
\hline 2 & 138000 & 85,000 & 140,000 & $1,250,000$ \\
\hline 3 & 152000 & 90,000 & $1,527,777$ \\
\hline 4 & 152000 & 90,000 & 1,000 & $1,388,888$ \\
\hline 5 & 143000 & 90,000 & $1,666,666$ \\
\hline 6 & 143000 & 90,000 & 1,666 \\
\hline 7 & 152000 & 90,000 & 150,000 & $1,763,888$ \\
\hline 8 & 152000 & 90,000 & $1,800,000$ & $1,666,666$ \\
\hline 9 & 143000 & 100,000 & 150,000 & $1,888,000$ \\
\hline 10 & 138000 & 90,000 & 160,000 & $1,250,000$ \\
\hline 11 & 152000 & 100,000 & 150,000 & $1,250,000$ \\
\hline 12 & 143000 & 90,000 & 160,000 & $1,944,000$ \\
\hline 13 & 143000 & 90,000 & 140,000 & $1,527,777$ \\
\hline 14 & 152000 & 100,000 & 140,000 & $1,944,000$ \\
\hline 15 & 148000 & 90,000 & 160,000 & $1,944,000$ \\
\hline 16 & 152000 & 100,000 & 150,000 & $1,666,666$ \\
\hline 17 & 152000 & 100,000 & 160,000 & $1,666,666$ \\
\hline 18 & 143000 & 90,000 & 160,000 & $2,138,888$ \\
\hline 19 & 143000 & 90,000 & 150,000 & 15,000 \\
\hline 20 & 152000 & 90,000 & 170,000 & \\
\hline
\end{tabular}

\section{Hasil dan Pembahasan}

Dari Tabel 2, kemudian dilakukan analisis korelasi yaitu pearson product, untuk mengetahui variabel mana yang memiliki hubungan yang kuat dengan variabel Biaya Pembangunan $/ \mathrm{m}^{2}$. Hasil yang diperoleh dapat dilihat pada Tabel 3.

Dari Tabel 3, dapat dilihat bahwa semua variabel yang akan diteliti memiliki korelasi positif terhadap variabel biaya konstruksi, artinya jika tiap variabel independen tersebut nilainya dinaikkan, maka nilai dari variabel dependen juga akan ikut naik. Selain itu, tiap variabel independen juga memiliki hubungan yang signifikan terhadap variabel dependennya, hal ini ditandai dengan nilai $\mathrm{p}$ value dari korelasi yang di bawah nilai alpha yang digunakan (5\%). Dari hasil tersebut kemudian dilanjutkan dengan menyertakan semua variabel independen untuk dianalisis menggunakan analisis regresi kuadratik.

Tabel 3. Hasil Analisis Korelasi

\begin{tabular}{|c|c|c|c|}
\hline Korelasi & $\begin{array}{c}\text { Bahan Baku (Pasir dan } \\
\text { Semen) (X1) }\end{array}$ & $\begin{array}{c}\text { Upah Tenaga Kerja / } \\
\text { Hari (X2) }\end{array}$ & $\begin{array}{c}\text { Batako/100 Buah } \\
\text { (X3) }\end{array}$ \\
\hline Biaya Konstruksi / $\mathrm{M}^{2}(\mathrm{Y})$ & 0,592 & 0,669 & 0,945 \\
\hline $\mathrm{P}$ value & 0,006 & 0,001 & 0,000 \\
\hline
\end{tabular}

Tabel 4. ANOVA (Pengujian Simultan Parameter Regresi Kuadratik)

\begin{tabular}{cccccc}
\hline Sumber Variasi & Df & SS & MS & F Hitung & F Tabel \\
\hline Regresi & 6 & $1.30235 \mathrm{E}+12$ & $2.17059 \mathrm{E}+11$ & 66.94514943 & $5.0709 \mathrm{E}-09$ \\
\hline Residual & 13 & 42150354276 & 3242334944 & & \\
\hline Total & 19 & $1.3445 \mathrm{E}+12$ & & & \\
\hline
\end{tabular}

Dapat dilihat dari Tabel 4, bahwa pengujian simultan persamaan regresi kuadratik yang terbentuk memiliki nilai
$\mathrm{F}$ hitung yang lebih besar daripada nilai $\mathrm{F}$ tabel, sehingga dapat disimpulkan bahwa secara serentak, persamaan 
regresi kuadratik yang terbentuk dari kasus biaya konstruksi rumah Type 45 di Sulawesi Tengah, signifikan (punya arti). Setelah itu, akan dilanjutkan dengan pengujian parsial tiaptiap variabel independen terhadap variabel dependen yang dapat dilihat pada Tabel 5 .

Dari Tabel 5 dapat disimpulkan bahwa variabel yang signifikan dalam persamaan regresi yang terbentuk adalah variabel $\mathrm{X} 1, \mathrm{X} 1^{2}, \mathrm{X} 3$ dan $\mathrm{X} 3^{2}$. Hal ini diindikasikan oleh nilai $\mathrm{p}$ value masing-masing variabel yang berada di bawah nilai alpha (5\%). Adapun variabel lainnya tidak signifikan karena nilai $p$ value nya lebih dari alpha $(0,05 / 5 \%)$. Sehingga akhirnya persamaan regresi kuadratik yang terbentuk adalah:

$$
\begin{aligned}
& \hat{y}=-649,15 X_{1}+0,0022 X_{1}^{2}+182 X_{3} \\
& -0,0005 X_{3}^{2}+\hat{e}
\end{aligned}
$$

Tabel 5. Pengujian parsial parameter Regresi Kuadratik

\begin{tabular}{ccccccc}
\hline Variabel & Coefficients & $\begin{array}{c}\text { Standard } \\
\text { Error }\end{array}$ & t-Statistic & P Value & Lower & Upper \\
\hline Intercept & 15348372.98 & 14990001.62 & 1.02390736 & 0.324555543 & -17035556.7 & 47732302.6 \\
\hline $\mathrm{X} 1$ & -649.1495687 & 264.3390403 & -2.455746105 & 0.028899187 & -1220.21935 & -78.0797913 \\
\hline $\mathrm{X} 1^{2}$ & 0.002253595 & 0.000901416 & 2.500060762 & 0.026585736 & 0.0003062 & 0.00420099 \\
\hline $\mathrm{X} 2$ & 368.3082978 & 186.7161589 & 1.972557169 & 0.070200164 & -35.0674396 & 771.684035 \\
\hline $\mathrm{X} 2^{2}$ & -0.001975316 & 0.000983929 & -2.007580293 & 0.065938717 & -0.00410097 & 0.00015033 \\
\hline $\mathrm{X} 3$ & 182.704223 & 54.60008117 & 3.346226215 & 0.005258729 & 64.747919 & 300.660527 \\
\hline $\mathrm{X} 3^{2}$ & -0.000512568 & 0.00017816 & -2.87700976 & 0.012967575 & -0.00089746 & -0.00012768 \\
\hline
\end{tabular}

Adapun koefisien determinasi dari persamaan regresi di atas adalah seperti pada Tabel 6 .

\begin{tabular}{c} 
Tabel 6. Koefisien Determinasi \\
\hline R square adjusted \\
\hline 0,95 \\
\hline
\end{tabular}

Artinya, variansi variabel dependen dapat dijelaskan 95\% oleh variansi variabel independen, dengan kata lain variabel bahan baku, upah tenaga kerja dan harga batako mempengaruhi biaya konstruksi sebesar 95\%.

\section{Kesimpulan}

Dari penelitian ini dapat disimpulkan bahwa hasil pemodelan regresi yang didapatkan adalah $\hat{y}=-649,15 X_{1}+0,0022 X_{1}^{2}+182 X_{3}-0,0005 X_{3}^{2}+\hat{e}$, dengan $\mathrm{R}^{2}$ sebesar $95 \%$, dimana variabel yang berpengaruh terhadap biaya konstruksi perumahan type 45 di Sulawesi Tengah pada model regresi kuadratik adalah bahan baku dan batako. Selanjutnya, untuk mengestimasi biaya konstruksi perumahan di Sulawesi Tengah, persamaan ini dapat digunakan dengan memasukkan nilai-nilai variabelnya pada data perumahan yang baru.

Untuk seorang estimator, formulasi dalam kesimpulan dapat digunakan sebagai pembanding atas estimasi yang telah dilakukan. Untuk peneliti untuk dapat melanjutkan penelitian yang sejenis terhadap proyek bangunan, jalan, jembatan, keairan dan lainnya.

\section{Daftar Pustaka}

[1] A. Musyafa, "Pengembangan Model Untuk Memprediksi Biaya Pembangunan Rumah Layak Huni Berdasarkan Harga Bahan", Jurnal Teknisia, vol. 21 no. 2 , p. $274,2016$.

[2] I.N.Y. Astana, "Estimasi Biaya Konstruksi Gedung Dengan Cost Significant Model", Media Teknik Sipil, vol. 13, no. 1, p. 30, 2013.

[3] P.A. Eman, E.M. Lintong, and F. Jansen, "Estimasi Biaya Konstruksi Menggunakan Metode Parameter
Pada Proyek Pemeliharaan Berkala Jalan di Kota Manado", Jurnal Ilmiah Media Engineering, vol. 8, no. 2, p. 1033, 2019.

[4] E.R Ahadian, and M. Rizal, "Estimasi Biaya Konseptual Konstruksi Jembatan dengan Metodeparameter", Jurnal Sipil Sains, vol. 8, no. 16, p. 42,2018

[5] H.R. Agustapraja, and N.A. Affandy, "Perbandingan Estimasi Anggaran Biaya Dengan Metode Sni Dan Bow Pada Proyek Pembangunan Gedung D Fakultas Agama Islam Universitas Islam Lamongan", UKaRsT, vol. 1, no. 2, p.84, 2017

[6] A. Permadi, R. Waluyo, and W. Kristiana, "Analisis Estimasi Biaya Konstruksi Menggunakan Analisis Harga Satuan Pekerjaan 2013 dan 2016", Jurnal Teknika, vol. 2, no. 1, p. 1, 2018.

[7] H.S.D Roring, "Estimasi Biaya Konstruksi Dermaga Dengan Metode Cost Significant Model", Jurnal Ilmiah Realtech, vol. 15, no. 1, p. 47, 2019.

[8] Y. Supriyatna, "Estimasi Biaya Konstruksi Pekerjaan Batu Dan Plesteran" Majalah Ilmiah UNIKOM, vol. 6, no. 2, p. 169, 2011.

[9] B.G. Hutchinson, Principles of Urban Transport Systems Planning, New York: McGraw Hill, 1974.

[10] I. Soeharto, Manajemen Proyek dari Konseptual Sampai Operasional, Jakarta: Erlangga, 1995.

[11] Pratt, Minimizing Waste of Contration, New Jersey: Prentices Hall Inc., 1995.

[12] N.R. Draper, H. Smith, and B. Sumantri, Analisis Regresi Terapan, Jakarta: PT Gramedia Pustaka Utama, 1992.

[13] D. Gujarati, Ekonometri Dasar, Jakarta: PT. Erlangga, 2003.

[14] S. Hadi, Analisis Regresi, Yogyakarta: Andi, 2004.

[15] H. Usman, and R.P.S. Akbar, Pengantar Statistika, Jakarta: Penerbit PT. Bumi Aksara,1995. 